Cronfa - Swansea University Open Access Repository

This is an author produced version of a paper published in :

Legal Studies

Cronfa URL for this paper:

http://cronfa.swan.ac.uk/Record/cronfa21845

\title{
Paper:
}

Jenkins, V. (2015). The legal response to safeguarding local environmental quality. Legal Studies, 35(4), 648-674. http://dx.doi.org/10.1111/lest.12088

This article is brought to you by Swansea University. Any person downloading material is agreeing to abide by the terms of the repository licence. Authors are personally responsible for adhering to publisher restrictions or conditions. When uploading content they are required to comply with their publisher agreement and the SHERPA RoMEO database to judge whether or not it is copyright safe to add this version of the paper to this repository. http://www.swansea.ac.uk/iss/researchsupport/cronfa-support/ 


\section{The Legal Response to Safeguarding Local Environment Quality}

\section{Dr Victoria Jenkins, Swansea University*}

\section{Introduction}

The local environment is best defined as 'the public spaces between the places in which we live, work and play'. ${ }^{1}$ The way in which we experience this public space has an important impact on our quality of life. This depends on the social interactions that take place, but also on its physical condition. For most people the local environment is an urban or 'built environment'; ${ }^{2}$ and the main concerns are issues relating to the cleanliness of our surroundings, such as dog fouling, litter, graffiti, fly-tipping and fly-posting. These are problems that attract little moral opprobrium, but have been proven, from both an empirical and theoretical perspective, to be of great significance to local communities. Yet, local environmental quality, as a measure of the aesthetic condition of public space, is an emerging concept that has not yet been fully articulated. This paper will argue that local environmental quality is an issue worthy of recognition and that we need to develop a comprehensive legal framework to address threats to the physical integrity of public space.

Safeguarding local environmental quality has been the primary responsibility of local government since the development of public health legislation in the $19^{\text {th }}$ century; but it is a role which has been traditionally undervalued. From the 1970s onward, increasing attention to this problem led to attempts to tackle threats to local environmental quality as local environmental crime; but this resulted in a piecemeal approach to the problem. In 1997, the election of a new Labour Government in the UK signalled a renaissance in the way in which we understand local environmental quality and the measures used to address this. Therefore, the Labour Government was keen to relate action on local environmental crime with measures to tackle the wider problems of incivility in society as part of its agenda for social justice. Many people are concerned by the state of the local environment, but this is considered more problematic for those living in the most deprived areas, who also suffer most from anti-social behaviour in the community. ${ }^{3}$ The Coalition Government pledged to introduce sweeping reforms to the anti-social behaviour laws created by their predecessors. These are now found in the Anti-Social Behaviour, Crime and Policing Act 2014 and this legislation will be particularly significant to the evolving legal framework for safeguarding local environmental quality.

\footnotetext{
*I would like to thank Stuart Macdonald, Mark Stallworthy, Andrew Millie, Patrick Bishop and the anonymous referees for their comments on previous drafts of this paper. However, I take full responsibility for any errors or omissions.

${ }^{1}$ This is based on a definition in Living Places: Cleaner, Safer, Greener (London: Department of the Environment, Food and Rural Affairs, 2002), p.9. This is discussed in detail below, but the definition used in this paper includes places in which we play as well as those in which we live and work.

${ }^{2}$ See further the Labour Government's Neighbourhood Renewal Strategy Bringing Britain Together: A National Strategy for Neighbourhood Renewal, (London: Social Exclusion Unit, 1998) Cmnd 4045 and Millie on anti-social behaviour Millie A., Anti-Social Behaviour (Oxford: OUP, 2009), Chapter 2.

${ }^{3}$ See further the Labour Government's Neighbourhood Renewal Strategy Bringing Britain Together: A National Strategy for Neighbourhood Renewal, (London: Social Exclusion Unit, 1998) Cmnd 4045 and Millie on anti-social behaviour Millie A., Anti-Social Behaviour (Oxford: OUP, 2009), Chapter 2.
} 
This paper aims to provide a clear statement of the meaning of local environmental quality and its importance to the quality of life of local communities; before considering the measures necessary to develop a comprehensive legal framework to respond anti-social acts threatening this. First, it will explore the evolution of legal responses to this problem to date; from statutory nuisance, to local environmental crime and anti-social behaviour. Noting the strengths and limitations of each of these approaches, the paper concludes that tackling threats to local environmental quality as anti-social behaviour has been most successful in: raising the profile of this issue; providing the opportunity to address a broad range of behaviours using preventive orders; and supporting the development of new approaches to inter-agency cooperation and the participation of local communities in devising preventive strategies. Nevertheless, it is suggested that the current legal framework fails to fully address the problems of local environmental quality. Therefore, the paper proposes several amendments to the Anti-Social Behaviour, Crime and Policing Act 2014 to ensure its effective application to threats to local environmental quality; as well as making some recommendations for new measures in this respect.

\section{The Significance of the Concept of Local Environmental Quality}

There is clear empirical evidence that the state of the local environment has an important impact on the quality of life of the local community. Indeed, the cleanliness of our surroundings is consistently held to be of greater significance than global warming or using up the Earth's resources. ${ }^{4}$ Tackling dog fouling and litter are cited as the top priorities for improving the local environment, with other key issues including fly-tipping, graffiti and fly-posting. ${ }^{5}$ This may make depressing reading for environmentalists, but social problems and concerns about local environmental quality cannot be divorced from wider issues of environmental degradation. This is clearly recognised in the international mandate for action on sustainable development - Agenda 21. ${ }^{6}$ Thus, although the notion of sustainable development is usually associated with action on global environmental issues, such as climate change, the sustainable communities' agenda has focused on means of addressing the social and environmental concerns of our most deprived neighbourhoods in an integrated way. ${ }^{7}$ In a developed nation such as the UK, those environmental considerations focus on local environmental quality; but, strategies for local sustainability have also attempted to engage communities in thinking more widely

\footnotetext{
${ }^{4}$ The Word on Our Street: A National Survey Measuring the Public's Perceptions of their Local Environment (London: Keep Britain Tidy, 2011).

${ }^{5}$ The Word on Our Street: A National Survey Measuring the Public's Perceptions of their Local Environment (London: Keep Britain Tidy, 2011).

${ }^{6}$ Earth Summit Agenda 21: The United Nations Programme of Action from Rio (United Nations, 1993).

7 See further J Agyeman Sustainable Communities and the Challenge of Environmental Justice (New York: New York University Press, 2005). In the UK context, see further Securing our Future (London: Department of Food and Rural Affairs, 2005), Ch 6, and on its application to Wales, V Jenkins Sustainable Communities in Wales: Developing a New Governance Approach to Local Sustainable Development in Wales Most Deprived Areas in Bishop P. and Stallworthy M., Environmental Law and Policy in Wales: Responding to Local and Global Challenges (UWP, 2013) 123-143.
} 
about environmental matters, as espoused in the mantra - Think Globally, Act Locally'. 8

Links between the state of the local environment and broader issues of crime and disorder in society have been made in American literature for many years; stemming from Wilson and Keller's, Broken Windows theory:

'Consider a building with a few broken windows. If the windows are not repaired, the tendency is for vandals to break a few more windows.

Eventually, they may even break into the building, and if it's unoccupied, perhaps become squatters or light fires inside. Or consider a pavement. Some litter accumulates. Soon, more litter accumulates. Eventually, people even start leaving bags of refuse from take-out restaurants there or even break into cars. $^{9}$

The theory of Broken Windows is not universally supported, but has had an important impact on government policy in the UK. ${ }^{10}$ It also gains continued support from empirical studies and maintains an enduring appeal to those interested in the quality of the local environment in the UK. ${ }^{11}$ However, we have yet to develop a comprehensive legal framework to tackle action resulting in damage to the aesthetic quality of public space. Since the $19^{\text {th }}$ century local government has stood at the forefront of measures to protect local environmental quality, and although clearly undervalued, an essential element of this has been a role in street cleansing. ${ }^{12}$ Poor local environmental quality has also been addressed through community

\footnotetext{
${ }^{8}$ Although the exact origins of the phrase 'Think Local, Act Global' are unknown it was widely adopted as a mantra for the local environmental movement at this time See further S Ward 'Think Globally, Act Locally': British Local Authorities and their Environmental Plans Environmental Politics (1993) 2(3) 453-478. On the importance of local action for global sustainable development see further O Riordan T. Globalism, Localism and Identity: New Perspectives on the Transition to Sustainability (Oxford: Routledge, 2002).

${ }^{9}$ G Kelling and J Wilson 'Broken Windows: The Police and Neighbourhood Safety' (1982) 249(3) Atlantic Monthly 29.

${ }^{10}$ It has been described as 'more in the nature of an interesting hypothesis than an empirically proven causal axiom.' P Roberts 'Penal Offences in Question' in A Von Hirsch and A Simester (eds) Incivilities Regulating Offensive Behaviour (Oxford: Hart, 2006) 1 at $p$ 36. There is also evidence for example that 'place-oriented police 'crackdowns', based on the broken windows principle, can significantly increase the probability of local residents feeling unsafe, and 'accordingly any fear reduction benefits gained by reducing disorder may be offset by the fact that the policing strategies employed simultaneously increase fear of crime' quoted in S Mackenzie et al, The drivers of perceptions of anti-social behaviour Research Report 34 (Home Office, 2010) with reference to J Hinkle and D Weisburd 'The Irony of Broken Windows Policing: a Micro-place Study of the Relationship Between Disorder, Focused Police Crackdowns and Fear of Crime' (2008) Journal of Criminal Justice, 36, pp 503-512.

${ }^{11}$ The House of Commons Environmental Audit Committee found evidence of the operation of this theory in practice. Environmental Audit Committee Environmental Crime: Fly-tipping, Fly-posting, Litter Graffiti and Noise (Ninth Report of Session 2003-04) HC 445, para 44. For evidence of the continuing significance of the theory, and some proof of these connections see statistics included in the most recent survey of local environmental quality in England. How Clean is England? The Local Environmental Quality Survey of England 2013-2014 (London: Keep Britain Tidy, 2014). This concludes that the 'overall presence of crime is far greater on streets where litter, graffiti and flyposting are present compared to those without these issues' (p.27).

${ }^{12}$ See n. 15 below.
} 
regeneration programmes which have operated in the UK since the 1970 s. $^{13}$ Such measures can even be specifically aimed at 'designing out' incidents of anti-social behaviour, such as better street lighting or the provision of litter bins; ${ }^{14}$ and, as discussed below, these programmes are increasingly concerned with the quality of the local environment. These initiatives can have an important role in 'restoring' public space to its proper physical condition and, to some extent, in taking preventive approaches to damage in the built environment. However, the focus of this paper is on the legal response to action resulting in physical damage to the aesthetic quality of public space. Before providing an assessment of how this framework should be developed, it is important to consider approaches that have been adopted in the past and their strengths and limitations. The paper begins by discussing the role of nuisance law, because, until the late $21^{\text {st }}$ century, local authorities were largely reliant on the law of statutory nuisance to tackle problems in the local environment.

\section{Nuisance Law and the Protection of Local Environmental Quality}

The Public Health Acts of 1848-1936 provided local authorities with responsibilities for street cleansing and statutory nuisance. ${ }^{15}$ This legislation placed local government at the forefront in safeguarding the local environment. ${ }^{16}$ The current statutory nuisance regime is found in the Environmental Protection Act 1990 (EPA 1990) which places local authorities under a duty to inspect their area, and consider any relevant complaints about a number of nuisances listed in s79 EPA $1990 .{ }^{17}$ Since the St Helens Smelting Company case it has been established law that nuisance may include repeated actions, that cause not just material injury to property but 'amenity' or 'sensible personal discomfort' arising from this, such as smells and noise. $^{18}$ Therefore, as in the St Helens case itself, nuisance law can be used to gain

\footnotetext{
${ }^{13}$ See further D Warburton Community and Sustainable Development: Participation in the Future (London: Earthscan, 2009).

${ }^{4} \mathrm{~S}$ Mackenzie et al, The drivers of perceptions of anti-social behaviour Research Report 34 (Home Office, 2010).

${ }^{15}$ Public Health Act 1936, s77 provided local authorities with a power to carry out street cleansing and a duty to do so if directed by central government. This duty was replaced by the Environmental Protection Act 1990, s89.

${ }^{16}$ In the early $20^{\text {th }}$ century these duties were pursued alongside wider responsibilities for natural resource management in the supply of utilities, control of water resources and land use planning. There is also the possibility however, of an individual action under Environmental Protection Act 1990, s80.

17 Statutory nuisances are defined as:

- Any premises in such a state as to be prejudicial to health or a nuisance.

- Smoke, fumes or gases, dust steam smell or other effluvia emitted from any premises such as to be prejudicial to health or a nuisance.

- Any accumulation or deposit or any animal kept in such a place or manner such as to be prejudicial to health or a nuisance.

- Any insects emanating from relevant trade or business premises or artificial light emitted from premises such as to be prejudicial to health or a nuisance.

- $\quad$ Noise (including from a vehicle) such as to be prejudicial to health or a nuisance.

Environmental Protection Act 1990, s 79(1).

${ }^{18}$ St Helens Smelting Company v Tipping (1865)11 E.R. 1483.
} 
redress for polluting activities that have wider environmental effects. ${ }^{19}$ Statutory nuisances are dealt with by the imposition of an abatement notice, contravention of which may result in a criminal penalty. Thus, statutory nuisance orders (SNOs) are a form of hybrid order which, although much maligned by criminal lawyers, have been used successfully and without controversy in this field for many years. ${ }^{20}$ This success is attributed to:

- The 'pedigree' of the system given its long history;

- The fact that the penalties have been developed pragmatically and do not include custodial sentences;

- The participation of local people in identifying problems; and,

- The focus on property which 'means that in many senses statutory nuisance avoids the really difficult cases to deal with - the marginalised and those with low stakes in society and the local community. ${ }^{21}$

Despite the success of SNOs in tackling local amenity issues, they cannot be used to address more modern problems arising in public space because the list of statutory nuisances in s79(1) EPA 1990 are defined with reference to their emission from premises or vehicles. ${ }^{22}$ The Environmental Protection Act 1990 includes provision to create new forms of nuisance and some additions have been made, such as noise from vehicles and artificial light; ${ }^{23}$ but statutory nuisance remains essentially concerned only with the 'natural environmental aspects of a neighbourhood' that do not normally threaten the aesthetic quality of public space. ${ }^{24}$ Indeed it does not even extend to aesthetic harm that may arise from unreasonable use of private land, such as the storage of unsightly waste. ${ }^{25}$

\footnotetext{
${ }^{19}$ See further J Lowry and R Edmunds Environmental Protection and the Common Law (Oxford: Hart, 2000). More recently these cases have become known as 'toxic tort' cases. In certain cases, nuisance law may be invoked even where planning permission has been granted for the activity in question. See further Coventry v Lawrence [2014] 4 All E.R. 517.

${ }^{20}$ L Etherington, 'Statutory Nuisance and Hybrid Orders: True Crime Stories?' (2012) 33(3) Statute Law Review 390. Dennis also notes that preventive orders have been used successfully in other fields. See further I Dennis Security, Risk and Preventive Orders in S Sullivan and I Dennis (eds) Seeking Security: Pre-empting the Commission of Criminal Harms (Oxford: Hart, 2012).

${ }^{21}$ L Etherington, 'Statutory Nuisance and Hybrid Orders: True Crime Stories?' (2012) 33(3) Statute Law Review 390, p.406.

${ }^{22}$ It should also be noted that the possibility of effective action against amenity nuisance in an urban environment is curtailed by the locality doctrine which dictates that 'what would be a nuisance in Belgrave Square would not necessarily be so in Bermondsey'Thesiger L.J., Sturges v Bridgman (1879) $11 \mathrm{Ch}$. D.852, 856. Although, this would not preclude a nuisance action in cases of property damage and is not relevant to the 'prejudicial to health' limb of statutory nuisance.

${ }^{23}$ Furthermore, the role of statutory nuisance is considered to have been unnecessarily restricted by the judiciary in their approach to the interpretation of the legislation. R Malcolm and J Pointing 'Statutory Nuisance: the sanitary paradigm and judicial conservatism' (2006) 18(1) Journal of Environmental Law 37, p 40.

${ }^{24}$ Pontin B Nuisance Law and Environmental Protection: A Study of Nuisance Injunctions in Practice (Devon: Lawtext Publishing Ltd, 2013), p176.

${ }^{25}$ Pontin B Nuisance Law and Environmental Protection: A Study of Nuisance Injunctions in Practice (Devon: Lawtext Publishing Ltd, 2013), p.177. Pontin discusses the American literature on the exclusion of aesthetic nuisance and considers this to be a key area of criticism of nuisance law in England and Wales.
} 
During the $20^{\text {th }}$ century, local authorities also used public nuisance injunctions (PNIs) to deal with problems associated with sewerage systems, sanitation and pollution. ${ }^{26}$ At first sight, the use of PNIs might also be considered to have greater potential in addressing modern threats to local environmental quality arising in public space, such as fly-tipping. Public nuisance encompasses any unlawful act or omission that endangers life, health, property, morals, or comfort of the public and may result in a criminal or civil law action. ${ }^{27}$ As a criminal action, public nuisance can incur an unlimited fine or even life imprisonment; but, in reality it is usually addressed by injunction. ${ }^{28}$ The use of PNIs is however, limited by the fact that the interference caused by the alleged public nuisance has to be fairly widespread in its effect. ${ }^{29}$ Having fallen out of popular use for some time, PNIs have been resurrected in recent times to deal with problems of incivility in society. ${ }^{30}$ However, their use has been directed at social problems, such as prostitution; ${ }^{31}$ and has been criticised on several grounds, including the fact that such behaviour is better addressed by antisocial behaviour interventions. ${ }^{32}$ Thus, both PNIs and SNOs have proved unsuitable in dealing with modern threats to the physical condition of public space. From the 1970s onwards, new measures were introduced to tackle specific problems, such as litter and fly-tipping, as local environmental crimes.

\section{From Nuisance to Local Environmental Crime}

The 1970s heralded the introduction of the modern era of environmental law marked, in particular, by the Control of Pollution Act 1974 (CPA 1974) under which local authorities gained new responsibilities to enforce controls over litter, fly-tipping, flyposting and the maintenance of waste land. ${ }^{33}$ The Local Government Act 1972 also provided local authorities with a general power to introduce rules 'for the good rule and governance of the local area' which have been used extensively to address threats to local environmental quality, such as dog fouling. ${ }^{34}$ Contravention of by-

\footnotetext{
26 J Spencer, 'Public Nuisance - A Critical Examination' (1989) 48 Cambridge Law Journal 55. Public nuisance actions can also be instigated by the Attorney-General or by an individual with the A-G's permission, termed a relator action.

${ }^{27} \mathrm{R}$ v Shorrock [1993] 3 All E.R. 917.

28 J Spencer, 'Public Nuisance - A Critical Examination' (1989) 48 Cambridge Law Journal 55.

${ }^{29}$ Attorney-General v P.Y.A. Quarries Ltd [1957] 2 QB 169.

${ }^{30}$ See further T Sagar 'Public Nuisance Injunctions against on-street sex workers?' (2008) Criminal Law Review 353.

${ }^{31}$ See further T Sagar 'Public Nuisance Injunctions against on-street sex workers?' (2008) Criminal Law Review 353.

32 The use of PNIs is considered to undermine the type of multi-agency approaches now adopted to address such behaviour. See further T Sagar 'Public Nuisance Injunctions against on-street sex workers?' (2008) Criminal Law Review 353. It has also been argued that PNIs should be obsolete anyway because according to Rimmington v Goldstein [2005] UKHL 63 there is a presumption that individuals will be prosecuted for a relevant statutory offence where it exists. J Spencer, 'Public Nuisance - A Critical Examination' (1989) 48 Cambridge Law Journal 55.

${ }^{33}$ The Control of Pollution Act 1974 provided a duty for local authorities to create a strategy for tackling litter (section 24); a power to issue notices in respect of the maintenance of waste land (defined as a garden, vacant site of open land the condition of which was causing serious injury to the amenity of the area) (section 65); and, for the removal of waste from land (section 16). Local authorities could also enter into arrangements with owner/occupiers of land to facilitate street cleaning (section 22). The Litter Act 1983 introduced penalties for leaving litter and publicity of these whilst Town and Country Planning Act 1971, s109 included an offence of fly-posting.

${ }^{34}$ Local Government Act 1972, s235. The penalty for this offence on summary conviction was a fine which could include a daily charge for a continuing offence (section 237). The Local Government Act
} 
laws and offences under the CPA 1974 were dealt with summarily, usually incurring fines as a criminal penalty. The introduction of these local environmental crimes demonstrates an increasing concern with the quality of the built environment; which was specifically recognised in the UK's first environmental strategy, published in 1990:

'Most people in Britain live in towns and cities. So if we are to have a good and healthy environment, it is vital that they are pleasant places in which to live and work, and that new developments and buildings improve the quality of life there. 35

Subsequently, the Environmental Protection Act 1990 introduced a new approach to the offences of litter and fly-tipping based on Fixed Penalty Notices (FPNs) and the use of hybrid orders, which have gained continued support as an appropriate means of enforcement of for these offences.

The Environmental Protection Act 1990 (EPA 1990) was a significant milestone in the modern evolution of environmental law. The centrepiece was a new system of integrated pollution control, accompanied by measures to regulate waste. ${ }^{36}$ Thus, not withstanding its significance to economic development in the public interest, the main thrust of the legislation was to address serious threats to human health and the environment arising from industry:

'Polluting the environment was no longer to be seen as a morally neutral, white collar crime, a natural consequence of life in an industrial world which fell to be regulated by bodies closely associated with industry. It was to be viewed with moral opprobrium, as a serious offence, to be penalised by significant penalties including imprisonment. ${ }^{, 37}$

Nevertheless, the legislation also included offences related to the quality of the built environment, in terms of littering and fly-tipping. Litter was becoming more problematic due to smokers, fast food packaging and plastic carrier bags; ${ }^{38}$ whilst flytipping was on the increase as controls on waste disposal progressively increased. ${ }^{39}$ The EPA 1990 increased the fines for these offences, but also introduced the option to provide an 'out of court disposal' in the form of a FPN for the offence of littering. ${ }^{40}$

1972 also gave local authorities powers to prosecute in any legal proceedings where they considered it expedient for the promotion or protection of the interests of the inhabitants of their area (Local Government Act 1972, s222).

${ }^{35}$ This Common Inheritance: Britain's Environmental Strategy (London: Department of the Environment, 1990), Cmnd 1200, p114.

${ }^{36}$ Environmental Protection Act 1990, parts I and II respectively.

${ }^{37}$ R Harris 'The Environmental Protection Act 1990 - Penalising the Polluter' (1992) Journal of Planning Law 515, p.515.

${ }^{38}$ This Common inheritance: Britain's Environmental Strategy (London: Department of the Environment, 1990), Cmnd 1200, p.197. The growing problems of litter were attributed to smokers, fast food packaging and plastic carrier bags

39 This Common inheritance: Britain's Environmental Strategy (London: Department of the Environment, 1990), Cmnd 1200, p.197.

${ }^{40}$ Environmental Protection Act 1990 s88. The option of a court hearing still applies for more serious offences. The offence of littering is to throw down, drop or otherwise deposit litter in a place open to the air and to which the public have access (s87 (1)-(3). The Act also explicitly states that convictions for this offence could be publicised by the local authority to help in the abatement of this problem $s 87$ 
Furthermore, local authorities could designate litter control areas in which they would have the power to issue abatement notices; ${ }^{41}$ whilst street litter control notices could be made against commercial or retail premises. ${ }^{42}$

Tackling threats to local environmental quality as environmental crime has several advantages over previous approaches based in nuisance: most importantly it is possible to address problems arising in public space, including one-off incidents; the imposition of criminal penalties increases the gravity with which this problem is perceived; and a criminal justice approach has a greater deterrent effect than nuisance law. However, local environmental crime suffers from a lack of moral opprobrium which makes it difficult to provide an appropriate sanction. This is a problem that plagues environmental crime more generally, but is considered particularly significant in the context of local environmental crime. ${ }^{43}$ The use of an 'out of court' disposal in the form of an FPN, in relation to local environmental crime, is therefore, significant in this regard.

Until the EPA 1990, FPNs had been used exclusively for motoring offences since the 1950s; but despite their long history, there is little empirical evidence with regard to their success. ${ }^{44}$ FPNs should provide an economic disincentive to individuals who might, for example, be tempted to drop litter in the street; but there is a danger that in some cases, such as fly-tipping, offenders may consider a FPN as more of a 'tax than a penalty' and consequently may fail to address their offending behaviour. ${ }^{45}$ Nevertheless, it is undoubtedly the case that it is not necessarily appropriate to impose sanctions for local environmental crime through the courts. The search for appropriate responses to local environmental crime reflects wider concerns about the need for more innovative approaches to sanctioning in criminal law, particularly for offences that are not considered very morally reprehensible. ${ }^{46}$ The administrative nature of many regulatory crimes for example, has led to the introduction of a range of civil sanctions including fixed monetary penalties, under the Regulatory Enforcement and Act Sanctions 2008 . $^{47}$ This was also clearly the motivation for the development of preventive orders to address anti-social behaviour.

(6). s33 of the Act provided for the offence of the unlawful deposit of waste. This was clearly directed at corporations involved in fly-tipping as waste from domestic properties is specifically excluded s33 $(2)$.

${ }^{41}$ Environmental Protection Act 1990 s90. Contravention of an abatement notice was a summary offence resulting in a level 4 fine, but could also include further payment at 1/20 of this fine for everyday that the offence continued after conviction (s92). An application could also be made to the Magistrates' court by an individual aggrieved by litter (s91). This mirrors the provision in respect of statutory nuisance under $\mathrm{s} 80$, see $\mathrm{n} 16$ above.

${ }^{42}$ Environmental Protection Act 1990 s93. Street litter control notices could be imposed on premises with a frontage on the street where the pavement outside, or adjacent open land, was continually defaced by litter resulting from the activities of those premises

${ }^{43}$ See further Environmental Audit Committee Environmental Crime and the Courts (Sixth Report of Session 2003-04) HC 126.

${ }^{44}$ A Ashworth and L Zedner 'Defending the Criminal Law: Reflections on the Changing Character of Crime, Procedure and Sanctions' (2008) Criminal Law and Philosophy pp 21-51.

${ }^{45}$ Local Environmental Enforcement - Guidance on the use of Fixed Penalty Notices (London: Department of the Environment, Food and Rural Affairs, 2007), p 47.

${ }_{46}$ A Ashworth Principles of Criminal Law (Oxford: OUP, 2013).

${ }^{47}$ See further R Macrory Regulatory Justice: Making Sanctions Effective (London: Better Regulation Executive, 2006). 


\section{The Labour Government and the Crime and Disorder Act 1998}

The end of the 20th century in the UK was marked by the introduction of a new era in British politics with the election of its first Labour Government for 18 years. Eager to pursue an agenda for social justice, Labour came to power promising an offensive on anti-social behaviour, in a bid to achieve greater respect within our society. ${ }^{48}$ The behaviour in question did not necessarily amount to a serious criminal offence but repeated anti-social acts were considered to be equally as distressing for the individuals concerned. ${ }^{49}$ Much like poor local environmental quality, anti-social behaviour was not considered to be a major issue for all of us but a significant problem in certain urban areas - particularly poorer residential areas. ${ }^{50}$ The agenda in the UK initially focused on neighbour nuisance as evidenced in the original Labour Party documentation A Quiet Life: Tough Action on Criminal Neighbours. ${ }^{51}$ Indeed, the term anti-social behaviour had first appeared in housing legislation, in 1996, making provision to mirror the operation of the law of nuisance in dealing with private landowners. ${ }^{52}$ However, a much broader approach was eventually adopted in Labour's new anti-social behaviour laws.

The cornerstone of the Labour Government's agenda for tackling anti-social behaviour was the Anti-social Behaviour Order or ASBO. The Crime and Disorder Act 1998 gave police and local authorities power to apply to the Magistrates Court for an ASBO on the grounds that (1) that the person has acted in an anti-social manner, that is to say, in a manner that caused or was likely to cause harassment, alarm or distress to one or more persons not of the same household as himself; and (2) that such an order is necessary to protect relevant persons from further antisocial acts by him. ${ }^{53}$ ASBOs, like SNOs and the orders associated with litter, were hybrid orders; breach of which, without reasonable excuse, was a criminal offence. However, the penalty in this instance was much higher - a term of up to five years imprisonment. ${ }^{54}$ The law on anti-social behaviour was further developed in a series of measures to create a more sophisticated three tiered approach comprised of warnings; acceptable behaviour contracts (ABCs); and court orders, including ASBOs and Criminal Anti-social Behaviour Orders (CrASBOs). ${ }^{55}$ An ABC was a written agreement between the individual and local authority/police consisting of a list of anti-social acts that the person agreed to desist from. They were not legally binding but could be used in court as evidence in an ASBO application. ${ }^{56}$ A CrASBO could be made on conviction in criminal proceedings either on the courts own

\footnotetext{
${ }^{48}$ Protecting our Communities: Labour's plans for tackling criminal, anti-social behaviour in neighbourhoods (Labour, 1996).

${ }^{49}$ E Burnsey Making People Behave: Anti-social behaviour, Politics and Policy (Willan, 2005), p19.

${ }^{50}$ A Millie Anti-Social Behaviour (Oxford: OUP, 2009), Chapter 2. See further n.3 above.

51 Labour Party A Quiet Life: Tough Action on Criminal Neighbours. (London: Labour Party, 1995).

${ }^{52}$ Housing Act 1996 defining anti-social behaviour as:

"Engaging in conducting, causing or likely to cause a nuisance or annoyance to a person residing in, visiting or otherwise engaging in lawful activity in residential premises..." (emphasis added). S152 Housing Act 1996.

${ }^{53}$ Crime and Disorder Act 1998, s1.

${ }^{54}$ This is punishable by up to five years imprisonment (in the case of adults) or a detention and training order of up to 24 months duration (in the case of under-18s).

${ }^{55}$ See further A Clarke et al, Describing and Assessing Interventions to Address Anti Social Behaviour Research Report 51 (London: Home Office, 2011).

${ }^{56}$ See further http://www.homeoffice.gov.uk/anti-social-behaviour/penalties/acceptable-behaviourcontracts.
} 
initiative or following an application by the prosecutor. ${ }^{57}$ CrASBOs were particularly important in dealing with serious, persistent offenders and this approach highlights the fact that ASBOs were not intended to replace existing criminal offences, but to be used an additional mechanism for dealing with such behaviour. In fact, the majority of interventions in cases of anti-social behaviour involved the use of CrASBOs in an attempt to prevent persistent offenders. ${ }^{58}$

The Crime and Disorder Act 1998 may be widely known for creating ASBOs but it also provided a legal framework to formalise arrangements for Crime and Disorder Partnerships (CDPs). ${ }^{59}$ This embraced the work of local authorities in community safety which many had been developing since the 1980s. ${ }^{60}$ CDPs were to bring together local agencies to create a strategy for the prevention of crime and disorder, on the basis of a 'review of the levels and patterns of crime and disorder in the area' that takes 'due account of the knowledge and experience' of local people. ${ }^{61}$ Thus, it presented a mechanism for an inter-agency and participative approach in creating preventive strategies. Furthermore, in 2001, the police were given powers to impose FPNs for many different types of social disorder by individuals such as, being drunk on a highway or using a pedal cycle or roller skates anywhere not designated for such use; ${ }^{62}$ whilst, in 2003, new orders were introduced to tackle specific social problems in public space, such as dispersal orders in respect of gangs of youths meeting on street corners. ${ }^{63}$

The Crime and Disorder Act 1998 introduced a new framework of measures for tackling anti-social behaviour that was widely considered to present a fresh approach to this problem. However, preventive orders had long been used to address statutory nuisances and specific problems, such as litter, in public space. ${ }^{64}$ The later introduction of FPNs also reflects experience in seeking appropriate responses to local environmental crime. Indeed, threats to local environmental quality have been described, much like anti-social behaviour, as 'low level' but persistent problems that nevertheless have an 'enormous impact' on quality of life, and felt most acutely in Britain's poorest communities. ${ }^{65}$ In fact, the quality of the physical environment in deprived neighbourhoods has been linked to increasing crime and disorder, as is

\footnotetext{
57 Section 1C (3) Crime and Disorder Act 1998 introduced under the Police Reform Act 2002.

$5860 \%$ of all orders issued between 1999 and 2013 were CRASBOs. Statutory Notice: Anti-Social Behaviour Order Statistics: England and Wales 2013 (London: Ministry of Justice, 2014).

59 S5 Crime and Disorder Act 1998.

${ }^{60}$ A Crawford The Local Governance of Crime (Oxford: OUP, 1999), p.34.

${ }^{61}$ S6 Crime and Disorder Act 1998. S6(2) states that before formulating a strategy, local authorities must "(a) carry out a review of the levels and patterns of crime and disorder in the area (taking due account of the knowledge and experience of persons in the area); (b) prepare an analysis of the results of that review; (c) publish in the area a report of that analysis; and (d) obtain the views on that report of persons or bodies in the area .... whether by holding public meetings or otherwise." The provisions for the involvement of local people are now made in regulations (Crime and Disorder (Formulation and Implementation of Strategy) Regulations 2007/1830), See further $n 112$ below.

62 Criminal Justice and Police Act 2001, s1.

63 Anti-social Behaviour Act 2003 s30.

${ }^{64}$ See $\mathrm{n} 17$ and 41-42 above.

65 This was the conclusion of the House of Commons Environmental Audit Committee on the crimes of fly-tipping, fly-posting, litter graffiti and noise. These were described as 'low level' crimes which nevertheless have 'an enormous impact upon the local environment' and which are 'seen as a particular area of concern by very many communities across the country.' Environmental Audit Committee Environmental Crime: Fly-tipping, Fly-posting, Litter Graffiti and Noise (Ninth Report of Session 2003-04) HC 445, p7.
} 
captured in the theory of Broken Windows. Thus, it is perhaps not surprising that, from the beginning of the $21^{\text {st }}$ century, the Labour Government began to relate action on anti-social behaviour to safeguarding local environmental quality in developing its 'Respect' agenda for tackling incivility in society. ${ }^{66}$ This has had significant consequences for the development of the legal framework on safeguarding local environmental quality.

${ }^{66}$ Respect and Responsibility - Taking a Stand Against Anti-social Behaviour (London: Home Office, 2003) Cmnd 5778. This also later became an essential element of its policy on sustainable communities.See further Securing our Future (London: Department of Food and Rural Affairs, 2005), Ch 6. 


\section{Relating Action on Local Environmental Quality to Anti-social Behaviour}

Action on anti-social behaviour was only one element of the Labour Government's agenda for social justice, which also encompassed a new Strategy for Neighbourhood Renewal (SNR). ${ }^{67}$ This was intended to sharpen the focus on community development work that had been carried out across the UK since the 1970 s. $^{68}$ Local environmental quality was considered key to the long term vision at the heart of this strategy: to create communities with 'lower worklessness; less crime; better health; better skills; and better housing and physical environment'. ${ }^{69}$ This 'joined up' approach to the problems of deprived, urban communities also led to the publication of an important cross-departmental policy document - Living Places, Cleaner, Safer, Greener - that considered the measures necessary to improve the living environment in our towns and cities. ${ }^{70}$ This represented a triumph of policy integration in recognising the importance of the physical environment to our quality of life: 'The quality of our public space affects the quality of all our lives. It affects how we feel about where we live, where we work and where our children play. ${ }^{.71}$ In particular, the report referred to the 'growing body of research analysing the relationship between local environmental quality, people's health, their fear of crime and the social and economic vibrancy of the community'; $;{ }^{2}$ and concluded from this that:

'Dirty and dangerous places encourage graffiti, vandalism and anti-social behaviour, which in turn undermine public confidence in them and lead people to avoid them. An unattractive and threatening local environment encourages people to use their cars for short journeys and to move to a better area if they can. It can discourage investment and lead to abandonment and dereliction. ${ }^{73}$

The report stated that it was necessary not just to take positive action to improve the physical environment, such as social housing regeneration or street cleansing, but to consider the regulatory framework for tackling behaviour that threatened the aesthetic quality of the local environment. This led to a review of the tools available

\footnotetext{
${ }^{67}$ Bringing Britain Together: A National Strategy for Neighbourhood Renewal, Cmnd Paper 4045 (London: Social Exclusion Unit, 1998).

${ }^{68}$ See $\mathrm{n} 13$ above.

${ }^{69}$ A New Commitment to Neighbourhood Renewal: National Strategy Action Plan (London: Social Exclusion Unit, 2001), p 8. The SNR was later supported by the New Deal for Communities scheme (NDC), an area-based funding programme to which the improvement of the physical environment was also central. 'The scheme adopted a wide range of initiatives to improve and develop the physical environment which included, inter alia, supporting the modernisation of social housing and improving the residential environment, including cleaning up public spaces, remodelling residential environments in a bid to design out crime, and introducing more green spaces, improving gardens and alleyways.' J Stanton 'Local Sustainable Development: Lessons Learned from the New Deal for Communities' (2012) 14(1) Environmental Law Review 26, p 37.

${ }^{70}$ Living Places: Cleaner, Safer, Greener (London: Department of the Environment, Food and Rural Affairs, 2002).

${ }^{71}$ Living Places: Cleaner, Safer, Greener (London: Department of the Environment, Food and Rural Affairs, 2002), Foreword.

${ }^{72}$ Living Places: Cleaner, Safer, Greener (London: Department of the Environment, Food and Rural Affairs, 2002), p11.

${ }^{73}$ Living Places: Cleaner, Safer, Greener (London: Department of the Environment, Food and Rural Affairs, 2002), p11
} 
to address local environmental quality. ${ }^{74}$ Crucially, this took place as part of a more wide-ranging review of the measures necessary to improve the response to all forms of anti-social behaviour. ${ }^{75}$ Thus, measures to address threats to local environmental quality were considered as an essential element of action on combating anti-social behaviour. The main problem areas were considered to be, not just fly-tipping and litter, but fly-posting, graffiti and noise; issues which were also raised at this time by the House of Commons Environmental Audit Committee in a special report. ${ }^{76}$ The primary response was not to address these issues using ASBOs, but to strengthen existing law in relation to these offences; ${ }^{77}$ in particular, by making provision for the use of FPNs. ${ }^{78}$ New powers were also vested in local authorities to clean up the damage caused by graffiti and recover the costs from the offender; a power that was later extended to fly-posting and fly-tipping. ${ }^{79}$ These measures were included in the Anti-social Behaviour Act $2003 ;{ }^{80}$ but shortly after, following the momentum created by the Living Places agenda, further measures were introduced under the Clean Neighbourhoods and Environment Act 2005. This legislation strengthened the existing provisions on litter, including the retention of receipts from FPNs for littering; ${ }^{81}$ introduced new criminal offences with respect to, animal nuisance, abandoned vehicles and audible intruder alarms; and provided that the main sanction for all local environmental crimes should be the use of FPNs. ${ }^{82}$

By the beginning of the $21^{\text {st }}$ century, local environmental crime was firmly established as an essential element of anti-social behaviour, alongside street crime

\footnotetext{
${ }^{74}$ Living Places: Cleaner, Safer, Greener (London: Department of the Environment, Food and Rural Affairs, 2002). This review and the increase in local authority regulatory powers in this area were welcomed by the House of Commons Select Committee on Housing Planning Local Government and the Regions. Living Places, Cleaner, Safer, Greener Eleventh Report of Session 202-2003 HC 673-I. ${ }^{75}$ Respect and Responsibility - Taking a Stand Against Anti-social Behaviour (London: Home Office, 2003) Cmnd 5778.

${ }^{76}$ Environmental Audit Committee, Environmental Crime: Fly-tipping, Fly-posting, Litter, Graffiti and Noise (Ninth Report of Session 2003-04) HC 445. These issues were identified as areas of law requiring special attention in the more general report by the Environmental Audit Committee on environmental crime and the courts (Environmental Audit Committee Environmental Crime and the Courts (Sixth Report of Session 2003-04) HC 126).

77 The act of graffiti was an offence under a number of different pieces of legislation, primarily the Criminal Damage Act 1971 and the Highways Act 1980. Fly-posting was an offence under the Town and Country Planning Act 1990 and statutory offences relating to noise date back to the Noise Abatement Act 1960.

78 The Anti-social Behaviour Act 2003 extended the use of FPNs to graffiti and fly-posting (s43).

${ }^{79}$ Anti-social Behaviour Act 2003, s48 and Clean Neighbourhoods and Environment Act 2005 ss31 and 43 respectively.

${ }^{80}$ See further N Padfield 'The Anti-social Behaviour Act 2003: the Ultimate Nanny State Act?' (2004) Criminal Law Review 712.

81 The Clean Neighbourhoods and Environment Act 2005 ss96-97. The House of Commons Select Committee on Housing Planning Local Government provided significant support for the retention of the receipts of FPNs by local authorities - measures which were included in later legislation with respect to litter. House of Commons Select Committee on Housing Planning Local Government and the Regions Living Places, Cleaner, Safer, Greener Eleventh Report of Session 202-2003 HC 673-I. The offence of littering was also extended to all open places (s18); a new system of litter clearing notices was introduced to replace litter abatement notices (s20); and, the power to issue street litter control notices was extended to vehicles and stalls (s71).

82 See further Clean Neighbourhoods and Environment Act 2005: dog control orders (ss 55-67); abandoned vehicles (ss10-14); and, audible intruder alarms (ss 69-81). FPNs were later also applied to offences committed under local authority bye-laws by the Local Government and Public Involvement in Health Act 2007.
} 
and nuisance neighbours. ${ }^{83}$ Nevertheless, the framework of local environmental offences represented a 'patchwork' approach to the problem of safeguarding local environmental quality. Furthermore, although the use of FPNs in response to these crimes was a welcome development, enforcement remained a key issue. Effective enforcement of local environmental crimes relies on resource intensive situational strategies such as, CCTV or a time limited 'crack down' on certain types of activity in a particular area. ${ }^{84}$ Local authorities were primarily responsible for this activity which could prove problematic given their competing political priorities, particularly in a time of austerity. However, aside from the development of the notion of 'local environmental crime', the association between local environmental quality and wider problems of incivility led to two further significant developments. First, the work of CDPs in providing preventive strategies for crime and disorder was specifically extended, from 2006 , to behaviour adversely affecting the local environment. ${ }^{85}$ Secondly, ASBOs themselves were sought by local authorities in some cases of damage to the physical environment, such as graffiti and fly-tipping.

The use of ASBOs in the context of local environmental quality might seem surprising given the need to establish 'alarm, harassment or distress' in order to seek an ASBO from the courts. ${ }^{86}$ This definition stems from the public order legislation of the 1980s which was designed to protect the public from threats to their person. ${ }^{87}$ This may be thought to exclude action against behaviour threatening the physical environment such as, fly-posting or graffiti; indeed, it has been argued that both might be considered valuable art forms. ${ }^{88}$ However, 'Contemporary legal usage of the term harassment suggests that the injury to the victim's feelings can be quite mild and certainly less than the causing of fear', 89 but, even if the level of 'harm' caused by behaviour threatening to damage the local environment could be objectively considered to meet this threshold, the anti-social nature of behaviour is judged by the perception of others. ${ }^{90}$ In fact, there is some evidence that the act itself must be witnessed. ${ }^{11}$ This would be problematic in many cases of damage to the

\footnotetext{
${ }^{83}$ See Home Office website, in 2010, at http://webarchive.nationalarchives.gov.uk/20100405140447/http://asb.homeoffice.gov.uk.

84 See for example the use of CCTV by Preston Council where images were posted on the internet in the hope that local people would 'shop' those filmed littering. 'Crackdown on litter outs reaps success' Lancashire Evening Post $3^{\text {rd }}$ February 2014. Another example is the time limited 'crackdown' by Swansea City Council involving a private enforcement company rather than their own officers. 'Swansea's crackdown on dog fouling and litter' South Wales Evening Post 16th September 2013. ${ }^{85}$ Crime and Disorder Act 1998, s6.

${ }^{86}$ Crime and Disorder Act 1998, s1. See n 53 above.

87 The phrase 'alarm distress or harassment' was initially used in Public Order Act 1986, s5. Under the title of harassment alarm or distress, this Act made it an offence inter alia to: use threatening, abusive or insulting words; or behaviour or disorderly behaviour. This replaced a previous offence under the Public Order Act 1936 aimed at addressing the use of threatening, abusive or insulting words or behaviour with intent to provoke a breach of the peace.

${ }^{88}$ For example, the work of Banksy now demands great sums of money. Furthermore, some academics have lamented the demise of posters in advertising as an important art form. M Frost et al, The Rise and Fall of the Poster: Street Talk (Victoria: Images Publishing Group, 2006), p. 32.

${ }^{89}$ P Ramsay 'What is Anti-Social Behaviour' (2004) Criminal Law Review 908, p.911.

90 See further P Ramsay 'What is Anti-Social Behaviour' (2004) Criminal Law Review 908, p.910.

${ }^{91}$ Gosport BC v Fareham Magistrates' Court [2006] EWHC 3047. This case involved an anti-social behaviour order made against someone riding a jet-ski at excessive speed. The order was quashed because there were no swimmers in the water at the time. The court found that to satisfy the term 'likely to cause' harassment, alarm or distress it was necessary to establish not only the presence of others, but that the behaviour had actually caused such feelings (para 20).
} 
physical environment which are caused by clandestine activities such as, fly-tipping and graffiti. Despite these potential legal obstacles, Magistrates have, in practice, been willing to impose ASBOs to prevent physical damage that has not been directly witnessed. ${ }^{92}$ A simple internet search would suggest that ASBOs have been most prevalent in respect of graffiti. ${ }^{93}$ Furthermore, local authorities were advised that their use in tackling fly-tipping should be considered best practice; ${ }^{94}$ and the power to apply for ASBOs was extended to the Environment Agency with this specific aim. ${ }^{95}$ Indeed, ASBOs have been uniquely applied to corporations in the context of flytipping and fly-posting. ${ }^{96}$

The use of ASBOs in the context of local environmental quality has not gained universal support. For example, it is a source of surprise and not a little condemnation among criminologists that:

'...the use of the term "anti-social", originally used to describe aggressive or selfish individual behaviour affecting neighbours has been adopted instead of the more neutral disorder to describe a diverse mix of environmental and human incivilities that affect neighbourhoods in a more impersonal and generalised way. ${ }^{, 97}$

\footnotetext{
${ }^{92}$ This includes the imposition of ASBOs for wildlife offences. For example, the first wildlife ASBO was imposed on a person convicted for the theft of rare bird eggs preventing him from travelling to Scotland for 10 years 'Egg Collector Given ASBO Preventing Travel to Scotland' BBC News $24^{\text {th }}$ February 2012 available at www.bbc.co.uk/news/uk-scotland. An ASBO was also imposed on a man involved in a number of poaching and hare coursing incidents 'Stokesley poacher is given an ASBO' Gazette Live $4^{\text {th }}$ August 2011 available at www.gazettelive.co.uk. They have also been applied to tackling off-road motorcycling in the countryside. See further V Jenkins and S Macdonald 'Keeping Off-roaders on Track: Addressing the Misuse of Off-Road Vehicles in Urban and Rural Settings' (2010) Journal of Planning and Environmental Law 1-124.

${ }^{93}$ The use of ASBOs in tackling graffiti was assisted by the introduction of a power for transport authorities, as well as local authorities and the police, to impose such orders. Crime and Disorder Act 1998 (Relevant Authorities and Relevant Persons) Order 2006/2137.

${ }^{94}$ Fly-tipping: Causes, Incentives and Solutions: A Good Practice Guide for Local Authorities (London: University College London, 2006). The first ASBO to be issued for fly-tipping on the application of a local council, was made against a man found dumping rubbish in a private capacity, in 2005 . 'First ASBO issued for fly-tipping' $28^{\text {th }}$ January 2005 BBC News available at http://news.bbc.co.uk/1/hi/england/kent/4217477.stm.

${ }^{95}$ The power was extended to the Environment Agency by the Crime and Disorder Act 1998 (Relevant Authorities and Relevant Persons) Order 2006/2137. It was estimated that the Agency would seek 50 stand alone ASBOS and 50 CRASBOs per annum Final Public Sector Regulatory Impact Assessment: Giving the Environment Agency the Power to Apply for ASBOs (London: Home Office, 2006), but between 2006 and 2009 only four CrASBOs were imposed in waste cases (Information from the Environment Agency, National Enforcement Database). Nevertheless, CrASBOs continue to be targeted to the small number of serial organised fly-tippers. For example, a 10 year CrASBO was imposed on a prolific fly-tipper in Bristol banning him from having anything to do with waste disposal: 'Bristol's Biggest Fly-tipper Jailed Bristol Post May $2^{\text {nd }} 2009$ available at http://www.bristolpost.co.uk/Bristol-s-biggest-fly-tipper-jailed/story-11308695-detail/story.html. ${ }_{96}$ See for example, the Sony case in which the company was forced to stop illegal fly-posting to advertise its artists after two of its executives were threatened with anti-social behaviour orders. 'Sony Backs Down in Fly-posting Row With Council' Telegraph 15th June 2004. The potential application of ASBOs to the corporate sector is an issue that has, so far, attracted little academic attention, but there are clearly important implications for the wider regulatory agenda.

${ }^{97}$ E Burney Making People Behave: Anti-Social Behaviour, Politics and Policy (Milton: Willan, 2005), p 167.
} 
It is certainly true that this was not the original intention behind the Labour Government's anti-social behaviour agenda which focused on neighbour disputes; ${ }^{98}$ but there have been significant advantages in considering threats to the physical local environment as anti-social behaviour.

\section{Tackling Threats to Local Environmental Quality as Anti-social Behaviour: A Beneficial Approach?}

Recognition that behaviour threatening local environmental quality is an important element of incivility in society was clearly advantageous in raising the profile of this issue during the period of the Labour administration. During this time the notion of local environmental crime, that had first emerged in the 1970s, was firmly established as an essential element of anti-social behaviour. However, this presented a piecemeal approach to the problem. Therefore, the possibility of using ASBOs to address threats to local environmental quality was welcomed by local authorities. ASBOs might be considered similar to SNOs and litter orders as a form of hybrid order. However, SNOs are restricted to threats arising from premises and vehicles whilst litter orders, as the name suggests, are focused on an individual problem in a defined area. In contrast, ASBOs could be addressed to individuals or businesses involved in anti-social acts anywhere, including public space. They could also incur heavier penalties than SNOs or litter orders, if breached. ${ }^{99}$ Furthermore, the option to impose CRASBOs after the commission of a criminal offence provided the means to address serious and persistent anti-social acts. This expansion of the tool kit for tackling threats to local environmental quality should ordinarily be welcomed, but ASBOs have attracted a great deal of criticism, which, if pertinent to their application in this context, could severely limit their effectiveness.

Perhaps the most important criticism of an approach to anti-social behaviour based on the use of court orders is that it treated a problem of social justice through the penal system. ${ }^{100}$ The system provided a means of early intervention, such as antisocial behaviour contracts, and ASBOs only resulted in criminal conviction if breached; but this 'regulatory approach' was viewed as no more than an 'escalator' to courts. ${ }^{101}$ Secondly, the 'hybrid' nature of ASBOs was viewed as a serious threat to traditional principles of criminal justice. ${ }^{102}$ Finally, the orders themselves were considered to present a challenge to basic liberal principles given the wide breadth of the definition of 'anti-social behaviour'. This facilitated the imposition of ASBOs in

\footnotetext{
${ }^{98}$ Protecting our Communities: Labour's Plans for Tackling Criminal, Anti-Social Behaviour in Neighbourhoods (Labour, 1996).

${ }^{99}$ The penalty for breach of an ASBO is up to 5 years imprisonment, but custodial sentences cannot be imposed for breach of SNOs or litter orders.

100 D Garland The Culture of Control: Crime and Social Order in Contemporary Society (Oxford: OUP, 2001).

${ }^{101}$ A Crawford 'Governing Through Anti-social Behaviour: Regulatory Challenges to Criminal Justice' (2009) 49 British Journal of Criminology 810.

102 See further A Ashworth Principles of Criminal Law (Oxford: OUP, 2013) Ch 3. And for a more detailed consideration in the context of anti-social behaviour, A Ashworth 'Social Control and 'AntiSocial Behaviour: the Subversion Of Human Rights?' (2004) 120 Law Quarterly Review 263.
} 
respect of behaviour as diverse as a suicidal woman, roaming pigs or noisy trampolinist; cases where the recipient had little culpability for their actions; ${ }^{103}$ Furthermore, severe restrictions could be placed on an individual's liberty: 'As antisocial behaviour is drawn so broadly and the future is so uncertain, precaution will often demand micro-restrictions that penetrate the minutiae of daily life.... 104 The criticisms of ASBOs are clearly significant, but it should be noted that they are not as pertinent to threats to the aesthetic quality of public space as they are to other forms of anti-social behaviour. Protecting the local environment from physical damage through the use of court orders does not attract the same controversy as 'social justice' problems, such as the eradication prostitution or begging in public places. ${ }^{105}$ Furthermore, most of the problems encountered with the use of preconviction ASBOs were compounded by the fact that the majority were imposed on young people; ${ }^{106}$ whilst many of those involved in instances of local environmental damage are adults or even corporations. There is also some evidence that ASBOs simply do not work. In 2013, 58\% of the ASBOs imposed since 2000 had been breached at least once; and the average number of breaches per individual was $5 .^{107}$ There are clearly examples of such cases with respect to local environmental damage, ${ }^{108}$ but the bare statistics require closer scrutiny. They make no distinction between pre and post conviction ASBOs and, cannot measure the deterrent effect of such orders on other potential offenders. Furthermore, and crucially in the context of local environmental quality, these statistics fail to differentiate between the type of behaviour addressed by the court order - particularly between environmental and other forms of anti-social behaviour. In reality there has been little comprehensive empirical study of the use of ASBOs during the time they were in use. ${ }^{109}$

Tackling local environmental quality as anti-social behaviour has not only led to the application of preventive orders to these problems, but significant changes in governance arrangements for safeguarding the local environment. Local authorities now work with a number of other agencies in CDPs to develop strategies for the prevention of crime and disorder including that affecting the physical environment. This has resulted in new measures to address local environmental quality and community safety problems in an integrated way, such as measures to promote crime prevention through environmental design. ${ }^{110}$ The strategies created by CDPs are now based on a strategic assessment that includes information on the matters

\footnotetext{
${ }^{103}$ MacDonald. S., 'A Suicidal Woman, Roaming Pigs And A Noisy Trampolinist: Refining The ASBO's Definition Of 'Anti-Social Behaviour' (2006) 69(2) Modern Law Review 183.

${ }^{104} \mathrm{R}$ Duff and S Marshall 'How Offensive Can You Get' in A Von Hirsch and A Simester (eds) Incivilities Regulating Offensive Behaviour (Oxford: Hart, 2006), 57-90.

${ }^{105}$ See further A Millie 'Anti-Social Behaviour, Behavioural Expectations and an Urban Aesthetic' (2008) 48(3) British Journal of Criminology 379 and D Baker 'A Critical Evaluation of the Historical and Contemporary Justifications for Criminalising Begging' (2009) 73(3) Journal of Criminal Law 212.

${ }^{106}$ See for example, S Macdonald and M Telford 'The use of ASBOs against young people in England and Wales: lessons from Scotland.' Legal studies (2007) 27(4) 604-629 and P Squires and D Stephen Rougher Justice: Anti-Social Behaviour and Young People (Milton: Willan, 2005).

107 Statutory Notice: Anti-Social Behaviour Order Statistics: England and Wales 2013 (London: Ministry of Justice, 2014).

${ }^{108}$ See for example, in a recent case of fly-tipping a company banned from transporting controlled waste in England and Wales following a previous conviction, was found guilty of dumping 3000 tyres within the same year. 'Fly-tipping gang sentenced' (2010) ENDS report 427, p8.

${ }^{109} \mathrm{~S}$ Hodgkinson and N Tilley 'Tackling Anti-Social Behaviour: Lessons from New Labour for the Coalition Government' (2011) 11(4), Criminology and Criminal Justice 283.

${ }^{110} \mathrm{C}$ Rogers Crime and Reduction Partnerships (Oxford: OUP, 2006).
} 
which local people think that local agencies should prioritise ${ }^{111}$ Thus the authorities are under a duty to engage with the local community in establishing their views on these issues. ${ }^{112}$ The development of forms of local governance that appeal to 'community, partnership and participation' are not specific to crime prevention; ${ }^{113}$ but considered a necessity for local authorities wishing to tackle complex issues, such as creating sustainable communities. ${ }^{114}$ In the context of criminal control, problems of legitimacy and accountability are particularly acute, but CDPs have nevertheless, gained academic support as well as that of the current Coalition government. ${ }^{115}$ Inter-agency approaches to issues of local environmental quality might be perceived as diluting the role of local authorities in protecting the local environment, but there is some evidence that there response to the new powers has been 'enthusiastic'; a fact which is attributed to their desire to 'see enhanced support for a traditional local authority role. ${ }^{116}$ Asserting a role in the protection of the local environment was particularly important for local government at the end of the $20^{\text {th }}$ century given the progressive transfer of responsibilities for pollution regulation to central agencies. ${ }^{117}$ Thus, although the police and Environment Agency can apply for preventive orders, local authorities have also taken the lead in using ASBOs to address problems in the local environment.

In summary, addressing threats to local environmental quality as part of the agenda for dealing with increasing incivility in society has had a positive effect by: increasing the gravity with which this problem is viewed; extending the 'tool kit' for dealing with these issues; and providing new opportunities to consider preventive strategies as part of inter-agency and participative approaches to crime and disorder. Thus, at the beginning of the $21^{\text {st }}$ century an entirely new approach had begun to emerge to both our understanding of threats to local environmental quality and the measures used to address this problem. Furthermore, criticisms associated with the use of ASBOs are not necessarily relevant to the application of preventive orders in this context. In 2010 however, a new Coalition Government was elected in the UK which was firmly of the belief that a radical overhaul of measures tackling anti-social behaviour was needed. ${ }^{118}$ This will have important consequences for the developing legal framework on safeguarding local environmental quality.

\footnotetext{
${ }^{111}$ Crime and Disorder (Formulation and Implementation of Strategy) Regulations 2007/1830, Regulation 7(e).

112 Crime and Disorder (Formulation and Implementation of Strategy) Regulations 2007/1830, Regulation 12.

${ }^{113}$ This is a reference to the terminology used by Crawford in A Crawford The Local Governance of Crime (Oxford: OUP, 1999).

${ }^{114}$ See for example the requirement in the Local Government Act 2000, s4 for local authorities, in England, to create a sustainable communities strategy after consulting and seeking the participation of other relevant parties. See further V Jenkins 'Learning from the Past: Achieving Sustainable Development in the Reform of Local Government' (2002) Public Law 130-15.

115 See further A Crawford The Local Governance of Crime (Oxford: OUP, 1999).

${ }^{116}$ E Burney Making People Behave: Anti-Social Behaviour, Politics and Policy (Milton: Willan, 2005), p 140.

${ }^{117}$ For example, local authorities were given wide powers with respect to waste regulation by the EPA 1990 (see further J Pugh-Smith 'The Local Authority as a Regulator of Pollution in the 1990s' (1992) Journal of Planning Law 103), but when the Environment Agency was formed, in 1996 (to take a holistic approach to the problems of environmental pollution) these powers were also transferred to it (Environment Act 1995, s2). However, local authorities do retain some control of the clean-up of contaminated land and air quality monitoring.

118 'Moving Beyond the ASBO' Speech by Theresa May $28^{\text {th }}$ July 2010.
} 


\section{Local Environmental Quality and the Reform of Anti-social Behaviour Laws}

The Coalition Government came to power, in 2010, promising sweeping changes in the approach to anti-social behaviour. The White Paper Putting Victims First discussed the proposals for reform around four key themes:

- Putting victims first: Focusing the response to anti-social behaviour on the needs of victims.

- Empowering communities: Protecting victims.

- Swift, effective action: Giving professionals the tools they need to protect victims.

- Long term solutions: Tackling the drivers of anti-social behaviour. ${ }^{119}$

It is clear from the White Paper that, in line with the Labour Government's original agenda, the main focus of the reforms was to protect victims from social disorder that has a significant impact on individuals living in the local neighbourhood. ${ }^{120}$ Nevertheless, these proposals also have serious implications for the development of legal approaches to safeguarding the local environment. The reforms were put into effect by the Anti-Social Behaviour, Crime and Policing Act 2014; the centre piece of which was the introduction of a new system of court orders to replace the ASBO the Injunction Preventing Harm and Disorder (IPHAD) and a Criminal Behaviour Order (CBO). The Act also introduced a number of measures aimed at establishing the community, and not outside agencies, as the main driver of responses to antisocial behaviour, which also have some significance in the context of local environmental quality. However, of most relevance are the provisions on Community Protection Notices (CPNs) and the Protection of Public Space Orders (PPSOs).

\section{Community Protection Notices and Protection of Public Space Orders}

A central theme of the reforms was the need to reduce the number of orders aimed at specific issues such as, the dispersal of young people or street littering. ${ }^{121}$ To this end, the new notices will replace the abatement notices previously discussed with respect to litter and graffiti/defacement removal. ${ }^{122}$ CPNs can be imposed on individuals or businesses to prevent conduct, of a persistent nature, that has a detrimental effect on the quality of life of those in the locality; and is unreasonable ${ }^{123}$

\footnotetext{
${ }_{119}^{119}$ Putting Victims First: More Effective Responses To Anti-Social Behaviour (2012) Cmnd 8367.

120 See n. 51 above.

121 These are examples of orders with reference to public space but others were directed at activities on premises such as closure orders and crack house closure orders Putting Victims First: More Effective Responses to Anti-Social Behaviour (2012) Cmnd 8367, p.24.

122 Putting Victims First: More Effective Responses to Anti-Social Behaviour (2012) Cmnd 8367, p.24. Also of some significance to local environmental quality were dog control orders and noisy premises closure orders.

${ }^{123}$ Anti-Social Behaviour, Crime and Policing Act 2014, s 43(1). The individual must be over 16. CPNs must state that the individual stop doing, or do, specified things or take reasonable steps to achieve specified results (s43(3)). They must also be aimed at preventing or reducing the effect of recurring behaviour or the risk of this (s43(4)).
} 
PPSOs can be imposed in respect of a designated area of public space, for up to three years, where activities are being carried on that have this effect or are likely to do so; and the activity is of a persistent or continuing nature and unreasonable (or likely to be so). ${ }^{124}$ The grounds for CPNs and PPSOs provide an approach that clearly makes connections between anti-social behaviour and quality of life for local communities. The definition is sufficiently wide to include any behaviour threatening local environmental quality which is now broadly recognised to have such an impact. Some criminal lawyers will, no doubt, lament the width of this definition, in the same way that criticism has been made of the definition of anti-social behaviour; but it has been argued above that this is less problematic in the field of local environmental quality. ${ }^{125}$ Failure to comply with a CPN or PPSO, without reasonable excuse, is a summary offence for which a FPN or fine can be imposed. ${ }^{126}$ The local authority also has the power to carry out remedial works on land open to the air or issue a notice to the owner of premises offering to carry out such works and recoup the costs from the perpetrator. ${ }^{127}$ With reference to the experience of using SNOs, the fact that the penalties for infringement are limited to a fine should help to ensure their success. ${ }^{128}$

PPSOs are similar to local authority by-laws, although the grounds for imposing such an order now reflect more modern understandings of local environmental quality and its significance to the quality of life of the community. ${ }^{129}$ The legislation clearly states that PPSOs should be preferred to the use of by-laws, and they will only be available to local authorities. ${ }^{130} \mathrm{CPNs}$ on the other hand, can cover many situations currently addressed by the statutory nuisance regime. The Explanatory Memorandum states that these orders will not replace abatement notices in statutory nuisance, but there is no legal bar to their use where the behaviour amounts to statutory nuisance. ${ }^{131}$ Unlike SNOs, CPNs can be applied to a wider range of behaviours and problems arising in public space as well as from premises. Unlike SNOs, CPNs can also be imposed by the police as well as local authorities, ${ }^{132}$ but it would be anticipated that, as in the case of ASBOs, local authorities would take the lead in using these orders to address issues relating to local environmental quality. PPSOs and CPNs should therefore, become the primary response to problems of local environmental quality and prove useful tools for CDPs that will continue to bring local agencies together to devise strategies for the prevention of crime and disorder. ${ }^{133}$ It will be important that the community are aware of the possibilities of using the new orders to address

\footnotetext{
${ }^{124}$ A PPSO can prohibit specified things being done in the restricted area, and be directed at all people or specific categories of people; and can also be time limited if necessary Section 59 AntiSocial Behaviour, Crime and Policing Act 2014.

125 See discussion at n 103 above.

${ }^{126}$ Although the possible fines for contravention of CPNs are higher in relation to individuals and can be substantially higher for businesses. The fine in respect of individuals contravening CPNs is up to level 4 but for a company the limit is $£ 20,000$ (section 48 Anti-Social Behaviour, Crime and Policing Act 2014). It is clearly envisaged therefore, that CPNs might also be applied to businesses which is important in addressing for example, fly-posting and fly-tipping. The fine for contravention of PPSOs is up to level 3. Anti-Social Behaviour, Crime and Policing Act 2014, s67.

127 Anti-Social Behaviour, Crime and Policing Act 2014 s47.

128 See n 21 above.

129 See $\mathrm{n} 34$ above. The power to issue by laws under the Local Government Act 1972 is made with reference to the need to ensure the 'good rule and governance 'of the local area.

130 Sections 59 and 70 respectively Anti-Social Behaviour, Crime and Policing Act 2014.

131 Explanatory Notes to the Anti-Social Behaviour, Crime and Policing Act 2014.

132 Anti-Social Behaviour, Crime and Policing Act 2014 s53.

133 See n 85 above.
} 
issues of local environmental quality as the experience of the use of SNOs suggests that their involvement in bringing complaints will be key. ${ }^{134}$

\section{Community Remedies}

CPNs and PPSOs may be the most obvious element of the new anti-social behaviour laws applying to the improvement of local environmental quality; but the Act also introduces 'community measures' that have potential to support a more participatory approach to tackling behaviour that threatens the local environment. This approach is underpinned by the Coalition Government's flagship initiative- the 'Big Society. ${ }^{135}$ This encourages local communities to take direct action to improve their circumstances:

'The Big Society puts individuals and groups in the driving seat and Government in an enabling role removing the barriers, where appropriate, which prevent others from taking responsibility. More empowered communities and a society where people are more involved in social action ... should lead to increased well-being, stronger communities and stronger social ties. ${ }^{136}$

Local communities have been encouraged to take part in the work of CDPs in creating strategies for the prevention of crime and disorder, but the new community measures aim to involve local people more directly in decision making. First, victims of anti-social behaviour will have a role in establishing appropriate responses; and, secondly, local people will be able to hold local agencies to account for their actions. However, the current construction of the legislation means that these new initiatives will not be easily applied in the context of safeguarding local environmental quality. There are two aspects to community remedies - the 'community trigger' and restorative justice measures.

\section{The Community Trigger}

The aim of the 'community trigger' is to provide local people with a right to require relevant agencies to react to persistent problems of anti-social behaviour. Local authorities are expected to have a central role in this process in providing the point of contact for people wishing to make an application for review. ${ }^{137}$ The legislation places a duty on local agencies to carry out an inter-agency review of the response to an allegation of ASB in the following circumstances: if there are three or more

\footnotetext{
${ }^{134}$ See n 21 above.

135 See further V Lowndes and L Pratchett 'Local Governance under the Coalition Government: Austerity, Localism and the 'Big Society" (2012) 38(1) Local Government Studies 21. The centrepiece of this policy is the Localism Act 2011 which provides new 'community rights' with respect to neighbourhood planning, buying local assets and even challenging local government to provide services.

${ }^{136}$ Mainstreaming Sustainable Development: the Government's Vision of What this Means in Practice (London: Department of the Environment, Food and Rural Affairs, 2011), p6.

137 See further Empowering Communities, Protecting Victims: Summary Report on the Community Trigger Trials (London: Home Office, 2013).
} 
related complaints or this is the conclusion of a review procedure. ${ }^{138}$ The review procedure may consider, in particular, the persistence of the anti-social behaviour about which the original complaint was made; the harm caused, or the potential for harm to be caused, by that behaviour; and the adequacy of the response to that behaviour. ${ }^{139}$ There will however, be an element of local discretion in establishing the criteria for review. ${ }^{140}$ Pilot studies suggest that the 'community trigger' will be used mostly in cases of 'neighbour' disputes; ${ }^{141}$ whilst the statutory guidance states that the main aim of the 'community trigger' is to encourage 'those who are most vulnerable, or may not otherwise engage with agencies, to report incidents of antisocial behaviour. ${ }^{142}$ Thus, the 'community trigger' is clearly not intended to hold local agencies to account for their responses to behaviour that threatens the aesthetic quality of their local environment. However, this is possible under the legislation as long as it is not circumscribed by the review criteria adopted; for instance, by focusing on the level of harm caused.

\section{Restorative Justice Approaches}

The second 'community measure' is the involvement of victims of anti-social behaviour in decisions about appropriate sanctions. Every local policing body will have a duty to create a community remedy document for its area. This is a list of actions which are appropriate for dealing with individuals who have engaged in antisocial behaviour, or committed a relevant offence, and are to be dealt with without court proceedings. ${ }^{143}$ This list will be drawn up after consultation with the Chief of Police, local authorities, community representatives and the wider public. ${ }^{144}$

Community remedies may be imposed by the police where they have evidence of, or an admission of guilt with respect to, anti-social behaviour or an offence. ${ }^{145}$

Reasonable efforts must also be made to obtain the views of the victim (if any) of the anti-social behaviour. ${ }^{146}$ The victim is defined as the person who seems to have been affected, or principally affected, by the anti-social behaviour. ${ }^{147}$ The involvement of victims in providing 'out of court' remedies for perpetrators of antisocial behaviour introduces an element of restorative justice to anti-social behaviour laws. Restorative Justice has been defined as 'a process whereby parties with a stake in a specific offence collectively resolve how to deal with the aftermath of the

\footnotetext{
${ }^{138}$ Anti-Social Behaviour, Crime and Policing Act 2014 s104(1).

139 Anti-Social Behaviour, Crime and Policing Act 2014 s104(4)-(5).

140 This was considered particularly important by the Home Affairs Select Committee in their prelegislative scrutiny of the Act (Home Affairs House of Commons Select Committee The Draft Antisocial Behaviour Bill: Pre-legislative Scrutiny Twelfth Report of Session 2012-2013 HC 836-I).

${ }^{141}$ See further Empowering Communities, Protecting Victims: Summary Report on the Community Trigger Trials (London: Home Office, 2013).

${ }^{142}$ Anti-Social Behaviour, Crime and Policing Act 2014: Reform Of Anti-Social Behaviour Powers: Statutory Guidance for Frontline Professionals (London: Home Office, 2014).

${ }^{143}$ Anti-Social Behaviour, Crime and Policing Act 2014, s101(2). The sanctions must have the purpose of (a) assisting in the person's rehabilitation; (b) ensuring that the person makes reparation for the behaviour or offence in question; or (c) punishing the person (Anti-Social Behaviour, Crime and Policing Act 2014, s101(3)).

${ }^{144}$ Anti-Social Behaviour, Crime and Policing Act 2014, s101(5). A community representative is defined as any individual or body appearing to represent the views of people who live in, work in, or visit the area (s101 (9)).

145 Anti-Social Behaviour, Crime and Policing Act 2014 s102(1) and (2).

146 Anti-Social Behaviour, Crime and Policing Act 2014 s102(3).

147 Anti-Social Behaviour, Crime and Policing Act 2014. s102(6)
} 
offence and its implications for the future. ${ }^{148}$ There is insufficient room here to discuss the notion of restorative justice in detail, suffice to note that, although such approaches remain very much in their infancy in the UK they have gained academic support. ${ }^{149}$ Lawyers are often the greatest critics of restorative justice given the importance of issues of accountability in the system of criminal justice. ${ }^{150}$ However, such approaches are considered particularly appropriate where an act is either criminal but not viewed as morally reprehensible or simply socially unreasonable, as in the case of anti-social behaviour. ${ }^{151}$

In an environmental context, the possibilities for restorative justice are generally underexplored, and the fact that it is not always easy to identify specific victims of environmental crime is clearly a potential barrier. ${ }^{152}$ However, there is a body of literature on 'community justice' which extends the notion of restorative justice to consider, not just the impact on individual victims but wider communities. ${ }^{153}$ Despite concerns about accountability and issues of representation, a participatory approach to the local governance of crime and disorder has some academic support. ${ }^{154}$ This is currently evident in the work of CDPs which ensures the involvement of local people in decision making on crime prevention strategies by local agencies. However, a 'community justice' approach would allow local people to be involved in decisions on the appropriate response to anti-social behaviour affecting them. Such approaches have the potential, not just contribute to the rehabilitation of the offender but a positive effect on the community itself:

'The involvement of community participation in deliberative forums affords the potential to encourage a stronger and more participatory civil society. It allows an approach to restorative justice that engages communities in owning and resolving problems...,155

Indeed, it has been argued that the public is more likely to get involved in 'restorative justice' than other decision making processes in government. ${ }^{156}$

\footnotetext{
148 T Marshall Restorative Justice: An Overview (London: Home Office, 1999), p.6.

149 See further J Braithwaite Restorative Justice and Responsive Regulation (Oxford: OUP, 2002).

150 See for example, Ashworth who demands 'further debate about and the division of functions between state, victims, offenders and communities: and far greater emphasis upon procedural safeguards' A Ashworth 'Responsibilities, Rights and Restorative Justice' (2002) British Journal of Criminology 578. Duff also argues that 'offenders should suffer retribution for their crimes: but the essential purpose of such punishment should be to achieve restoration.' $R$ Duff 'Restorative Punishment and Punitive Restoration' in L Walgrave (ed) Restorative Justice and the Law (Milton: Willan, 2002) 82.

${ }^{151}$ E Burney 'Talking Tough, Acting Coy: What Happened to ASBOs' (2002) 41(5) Howard Journal of Criminal Justice 469.

152 See further C Boyd 'Expanding the Arsenal for Sentencing Environmental Crimes: Would Therapeutic Jurisprudence and Restorative Justice Work' (2007) 32 William \& Mary Environmental Law and Policy Review 483.

${ }^{153}$ See further A Crawford and R Todd 'Community Justice': Transforming Communities Through Restorative Justice' in E McLaughlin E. et al (eds) Restorative Justice: Critical Issues (London: Sage, 2003) 215, p 216.

154 See for example, A Crawford The Local Governance of Crime (Oxford: OUP, 1999).

155 A Crawford 'The State, Community and Restorative Justice: Heresy, Nostalgia and Butterfly Collecting' in L Walgrave (ed) Restorative Justice and the Law (Milton: Willan, 2002) 101, p 120

${ }^{156}$ See further Braithwaite J., Restorative Justice and Responsive Regulation (Oxford: OUP, 2002).
} 
In summary, community remedies have significant potential in promoting participative approaches to tackling behaviour threatening local environmental quality. However, the current legal framework does not clearly facilitate their application to such problems. First, if the review procedure under the community trigger relies heavily on the level of harm caused it is unlikely that it will be used to consider responses to problems such as, littering and dog fouling. Secondly, with regard to restorative justice approaches, there is a requirement to consult with local authorities in drawing up the 'community remedy document', but no specific mandate to include actions that will promote local environmental quality. Furthermore, only the police have the power to consider the appropriate action from this document, with respect to a particular individual. They must also confer with the victim of the anti-social behaviour, defined as the person principally affected. There will rarely be such a singly identifiable victim of local environmental damage which by its very nature affects the community at large. However, it should be noted that the legislation is somewhat ambiguous as there are also other references to 'victims' in the same section. ${ }^{157}$

\section{Injunctions Preventing Harassment and Disorder and Criminal Behaviour Orders}

The 'headline' provisions of the Anti-Social Behaviour, Crime and Policing Act 2014 were those replacing the ASBO with new IPHADs and CBOs. IPHADs may be ordered where the court is satisfied that, on the balance of probabilities, the respondent has engaged or threatened to engage in anti-social behaviour; and it considers it just and convenient to grant the injunction for the purpose of preventing this. ${ }^{158}$ IPHADs should meet concerns about the hybrid nature of the ASBO, ${ }^{159}$ but the definition of anti-social behaviour remains unchanged. ${ }^{160}$ Just like the CRASBO, the $\mathrm{CBO}$ will be a civil preventative order that can be attached to conviction; ${ }^{161}$ breach of which continues to attract a criminal penalty with a maximum sentence of five years. ${ }^{162}$ However, both IPHADs and CBOs can now include positive requirements on the individual as well as negative restrictions and these must be supervised by a specified individual or organisation. ${ }^{163}$ The new measures thus provide a clear attempt to add the option of 'more holistic support-based solutions' alongside the 'enforcement' approach based on court orders. ${ }^{164}$ However, this will

\footnotetext{
${ }^{157}$ Anti-Social Behaviour, Crime and Policing Act 2014, S102(5). In this subsection it is recognised that there may be more than one victim and they may have differing views on the appropriate remedy. 158 Anti-Social Behaviour, Crime and Policing Act 2014, s1.

159 This was argued by Macdonald and Hoffman. S Macdonald and S Hoffman 'Should ASBOs be Civilized' (2010) 6 Criminal Law Review 457.

${ }^{160}$ I.e., as conduct that has caused, or is likely to cause, harassment, alarm or distress to any person Anti-Social Behaviour, Crime and Policing Act 2014 s2. The Coalition Government was committed to defining anti-social behaviour in broad terms stating that '(it) remains a useful concept that focuses the police and other local agencies on the issues that matter most to people's daily lives...' More Effective Responses to Anti-Social Behaviour (London: Home Office, 2011), p8

${ }^{161}$ Anti-Social Behaviour, Crime and Policing Act 2014 s22. However, it does specifically include conduct capable of causing nuisance or annoyance in a housing context.

162 Anti-Social Behaviour, Crime and Policing Act 2014 s30.

163 Anti-Social Behaviour, Crime and Policing Act 2014, ss3 and 24. In deciding what requirements to include in the order the court must consult this individual/organisation as to their suitability and enforceability.

${ }^{164} \mathrm{~S}$ Hodgkinson and N Tilley 'Tackling Anti-Social Behaviour: Lessons from New Labour for the Coalition Government' (2011) 11(4), Criminology and Criminal Justice 283, p 295.
} 
clearly be resource intensive and it has been noted that it will be difficult for the prosecutor 'to satisfy the court that a relevant authority was in a position to satisfy or discharge any positive requirement. ${ }^{165}$ IPHADs and CBOs will continue to be very significant in the approach to tackling anti-social behaviour and, indeed, the Coalition Government's agenda has been criticised for failing 'to move beyond the model of using coercive court orders to deal with anti-social behaviour. ${ }^{, 166}$ As outlined above however, the use of preventive orders in safeguarding local environmental quality is less controversial and these orders should continue to be sought by local authorities as well as the police and the Environment Agency where relevant. ${ }^{167}$ Nevertheless, their use may potentially be restricted by Magistrates, in future, in light of the continued approach to the definition of anti-social behaviour based on the need to prove harassment, alarm or distress. ${ }^{168}$

\section{Next steps}

The Anti-social Behaviour, Crime and Policing Act 2014 introduced some bold measures that may significantly impact on action taken by local agencies to safeguard local environmental quality. CPNs and PPSOs will be particularly significant in this regard and the grounds for imposing these orders reflect modern understanding of the significance of local environmental quality to the quality of life of the community. They should soon largely replace the use of SNOs and by-laws in attempting to tackle these problems. However, it will be important to ensure that sufficient information is provided to communities about CPNs and PPSOs to allow the community to play its part in bringing problems to the attention of the council. The remaining measures in the Act were clearly intended to focus on victims of directly threatening behaviour, rather than that affecting the quality of the physical environment in the local community. Nevertheless, the new court orders and community measures also have the potential to impact on legal approaches to safeguarding local environmental quality; and this could be achieved with a few simple changes to the current legal framework.

ASBOs proved a useful additional tool in tackling threats to local environmental quality, and did not attract the same consternation in this context as in tackling other forms of anti-social behaviour. CrASBOs were also particularly important in addressing serious and persistent cases of damage in the local environment, for example with respect to fly-tipping. It will be important therefore, that IPHADs and especially CBOs are made available to address problems of local environmental quality, and this could be facilitated by a specific amendment to the definition of antisocial behaviour. As outlined above, a similar amendment to the wording of the legislative framework for CDPs has been beneficial in extending the work of these partnerships to issues regarding local environmental quality. ${ }^{169}$ CDPs have already played an important part in developing participatory approaches to the prevention of crime and disorder in the local area. Notwithstanding concerns about representation

\footnotetext{
165 S Ireland 'ASBOs are Dead, long Live ASBOs' (2011) 86 Criminal Justice Matters 26.

166 S Ireland 'ASBOs are Dead, long Live ASBOs' (2011) 86 Criminal Justice Matters 26, p.27.

167 Anti-Social Behaviour, Crime and Policing Act 2014 s1. They may also be sought by Natural Resources Wales, in Wales.

168 See n 91 above.

169 See n 85 above.
} 
and accountability, there is support for such participatory approaches to the local governance of crime. ${ }^{170}$ Similarly, citizen participation has been identified as an essential element of successful neighbourhood renewal strategies in tackling the problems of sustainable communities. ${ }^{171}$ In this context, citizen participation is considered important in contributing local knowledge to provide better solutions to the problems of these communities and in ensuring trust and confidence in the decisions made. ${ }^{172}$ It is a primary contention of this paper that, in future, this focus on participation should be extended to measures taken against those engaged in behaviour that threatens local environmental equality. The first steps will be to make some amendments to the Anti-social Behaviour, Crime and Policing Act 2014 to extend the existing provisions on community remedies and restorative justice approaches to problems arising in the context of local environmental quality. However, it is also important to consider how more participative approaches might be developed in the future.

The main measure of the success of restorative justice approaches is the extent of rehabilitation of the 'offender' and one way in which this is achieved is through the educative nature of the 'deliberative' process. ${ }^{173}$ The educational value of a process of 'community justice' can also extend to the wider community; and can be viewed as a means of 'social learning' to support broader environmental citizenship:

'In broad terms, learning is supposed to take place when individuals and organisations appreciate that their private interests are closely associated with broader social interests such as environmental protection. ${ }^{174}$

This leads on to a second important assertion of this paper that there should be greater attention to education in safeguarding local environmental quality. Public education also has an important role in 'engendering civic pride' and could clearly be part of a preventive strategy; ${ }^{175}$ but educational courses might also be offered to individuals who have been involved in anti-social acts affecting local environmental quality. Here, we might, once again, draw on the experience of tackling motoring

\footnotetext{
${ }^{170}$ See further A Crawford The Local Governance of Crime (Oxford: OUP, 1999).

171 See further J Stanton Democratic Sustainability in a New Era of Localism (London: Routledge, 2014). There is also wide-ranging commitment the importance of participation in decision making on more mainstream concerns in environmental protection such as, pollution. In this context, participation is considered important in improving the quality of decision making by eliciting public values to inform decisions in an age of scientific uncertainty and adopt a problem solving approachM Lee and C Abbot, 'The Usual Suspects? Public Participation Under the Aarhus Convention' (2003) 66 MLR 80 .

${ }^{172}$ See further J Stanton Democratic Sustainability in a New Era of Localism (London: Routledge, 2014).

${ }^{173}$ On restorative justice as a deliberative process, see further J Braithwaite Restorative Justice and Responsive Regulation (Oxford: OUP, 2002) at p.45. On the educative nature of such deliberative processes see further I. Young 'Communication and the Other' in S Benhabib (ed) Democracy and Difference (Princeton: Princeton University Press, 1996), p 34.

${ }^{174}$ This quote is taken from Holder who discusses the concept in relation to the deliberative process involved in environmental assessment. Holder J Environmental Assessment: The Regulation of Decision Making (Oxford: OUP, 2004), p197.

${ }^{175}$ This was the conclusion of the House of Commons Select Committee on Housing Planning Local Government and the Regions in 2003. The Committee therefore encouraged support for groups such as Groundwork. House of Commons Select Committee on Housing Planning Local Government and the Regions Living Places, Cleaner, Safer, Greener (Eleventh Report of Session 2002-2003) HC 673I.
} 
offences. ${ }^{176}$ Such offences are now often dealt with not by FPNs, but allowing perpetrators to attend a 'speeding' course. These have had some success in changing driver's attitudes to speeding; ${ }^{177}$ and such an approach could work equally well for people involved, for example, in littering and dog fouling. In these cases helping individuals to understand the wider impacts of their behaviour may prove to be a more effective means of prevention than FPNs. Such educational courses also have an important advantage in terms of resourcing, as not only are they funded by those responsible, but an element of this financing can be used in law enforcement. ${ }^{178}$ Identifying funding routes for enforcement is particularly important in safeguarding local environmental quality because effective enforcement strategies are resource intensive. ${ }^{179}$

\section{Conclusions}

This paper has clearly articulated the concept of local environmental quality and established its importance to the quality of life of local communities. Therefore, the paper argues for a comprehensive legal framework to tackle anti-social acts affecting local environmental quality. Safeguarding local environmental quality, understood as the aesthetic complexion of public space, has gained increasing significance to the public and policy makers alike. However, the role of local authorities in maintaining the condition of public space has traditionally been greatly undervalued and until the late $20^{\text {th }}$ century the condition of public space relied solely on the activities of local government in street cleansing and pursing the abatement of statutory nuisances. In the 1970s, community regeneration programmes were developed to address the quality of the living environment; and this coincided with the development of modern environmental laws to tackle problems in the built environment. Measures were put in place to tackle specific threats as local environmental crime; but this resulted in a piecemeal approach to the problem. However, threats to local environmental quality have also been considered as part of the developing agenda for tackling the wider problems of incivility in society. The introduction of new anti-social behaviour laws has presented the opportunity for local authorities to tackle a wide range of behaviours using preventive orders; and their application in this context has been less controversial than in relation to 'social problems'. In addition, it has provided a focus on inter-agency and participatory approaches to the prevention of crime and disorder affecting local environmental quality. However, the paper argues the current legal framework has emerged incrementally and without clear attention to the specific problem of local environmental quality. The main assertion of this paper is that some amendments to the current legal framework for tackling anti-social behaviour should be made to ensure its effective application to problems encountered in safeguarding local environmental quality. This should ensure that local authorities continue to take the lead on action to address this problem. Furthermore, some new measures should be introduced to place citizen participation

\footnotetext{
${ }^{176}$ As outlined above, the response to local environmental crime also drew on the experience of using FPNs for motoring offences. See n 44 above.

177 See further C Stephenson et al., Road Safety Research Report No. 115 (London: Department of Transport, 2010) and F McKenna Behavioural Research in Road Safety Seventeenth Seminar 2007 (London: Department of Transport, 2009).

${ }_{778}$ Historically, some receipts from FPNs have also been retained by local authorities. See n. 81 above.

${ }^{179}$ See n. 84 above.
} 
and education at the forefront of a comprehensive legal framework for safeguarding local environmental quality. 